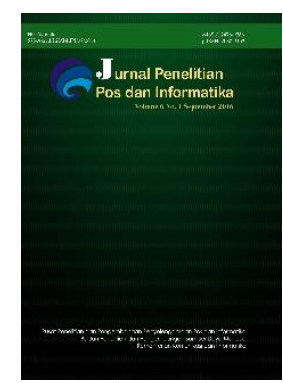

JPPI Vol 6 No 2 (2016) 113 - 136

\author{
Jurnal Penelitian Pos dan Informatika \\ 578/AKRED/P2MI-LIPI/07/2014 \\ e-ISSN 2476-9266 \\ p-ISSN: 2088-9402
}

DOI: 10.17933/jppi.2016.060201

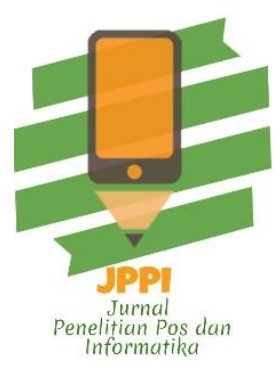

\title{
IMPLEMENTASI TEKNOLOGI BIG DATA DI LEMBAGA PEMERINTAHAN INDONESIA
}

\section{IMPLEMENTATION OF BIG DATA TECHNOLOGY IN GOVERNMENT INSTITUTIONS IN INDONESIA}

\author{
Emyana Ruth Eritha Sirait \\ Puslitbang APTIKA dan IKP - Kementerian Komunikasi dan Informatika \\ Jalan Medan Merdeka Barat Jakarta 10110 - Indonesia \\ emya001@kominfo.go.id
}

Naskah Diterima: 07 September 2016; Direvisi : 29 Oktober 2016; Disetujui : 23 November 2016

\begin{abstract}
Abstrak
Peranan data sangat penting terutama memasuki era ledakan data atau "Big Data". Oleh karenanya, pihak yang mampu mengolah dan memanfaatkan data-data yang bervolume besar, cepat berubah, variatif, dan kompleks, dapat mengambil keuntungan yang besar. Mengacu pada manfaat besar yang dapat ditawarkan oleh teknologi Big Data, menarik untuk melihat sejauh mana teknologi Big Data sudah dimanfaatkan di Indonesia, khususnya di lembaga pemerintahan, dan tantangan apa saja yang muncul dalam penerapannya. Diharapkan hasilnya dapat memberikan informasi dan inspirasi sehingga implementasi teknologi Big Data di Indonesia dapat semakin luas. Pengumpulan data pada penelitian ini dilakukan melalui teknik wawancara mendalam kepada pengelola teknologi informasi di empat instansi: Lembaga Kebijakan Pengadaan Barang/Jasa Pemerintah (LKPP), Pemerintah Kota Bandung, Direktorat Jenderal Pajak Kementerian Keuangan, dan Badan Informasi Geospasial (BIG). Deskripsi kualitatif yang didapat kemudian dianalisis dengan TDWI Big Data Maturity Model. Hasilnya dapat disimpulkan bahwa tiga instansi dapat dikategorikan berada pada tahap pre-adoption, hanya Pemerintah Kota Bandung yang telah berada pada tahap corporate adoption.
\end{abstract}

Kata kunci: Big Data, Lembaga Pemerintahan, Tantangan, Implementasi, Big Data Maturity Model.

\begin{abstract}
The role of data is very important, especially in the era of data explosion or "Big Data". Therefore, the parties which are able to process and utilize huge volume, rapidly changed, varied, and complex data can take large advantages. Considering big potential offered by Big Data technology, it is exciting to research how Big Data has been implemented in Indonesia, especially in several government agencies, and find the raising challenges in its application. It is expected that this paper can provide information and inspiration to widespread the implementation of Big Data technology in Indonesia.This research uses depth interview technique in data collecting to the administrators of information technology in four institutions: National Public Procurement Agency (LKPP), Government of Bandung City, Directorate General of Taxes Ministry of Finance, and Geospatial Information Agency. The qualitative description is then analyzed according to TDWI Big Data Maturity Model. It can be concluded that the three institutions are on pre-adoption step, while Government of Bandung City is already in corporate adoption level.
\end{abstract}

Keywords: Big Data, Government Agencies, Challenges, Implementation, Big Data Maturity Model 


\section{PENDAHULUAN}

Melalui teknologi informasi, triliunan byte data diciptakan setiap hari dari berbagai sumber, seperti dari media sosial, sensor, video surveillance, dan smart grids. Lautan data ini mengarah pada satu terminologi Big Data. Data memiliki peran penting dalam pengambilan keputusan strategis. Oleh karenanya, pihak yang mampu mengolah dan memanfaatkan data-data yang tersedia dalam volume besar, keragaman variatif, kompleksitas tinggi dan kecepatan penambahan data yang tinggi, dapat mengambil keuntungan yang besar. Namun sayangnya, penerapan Big Data analitik masih belum begitu populer di Indonesia ${ }^{1}$. Sejauh ini tiga bidang usaha pengguna utama Big Data di Indonesia yaitu perusahaan telekomunikasi, perbankan, dan produsen barang-barang konsumsi ringan dan murah seperti minuman dan makanan kemasan (consumer goods).

Teknologi Big Data sebenarnya dapat dimanfaatkan oleh banyak pihak, baik perusahaan besar, usaha kecil dan menengah, maupun pemerintah. Meski pemanfaatan Big Data terbilang rumit dan mahal, namun UKM bermodal kecil pun bisa memanfaatkannya asal tahu persis tujuan bisnisnya sehingga memudahkan proses identifikasi data yang dibutuhkan, untuk mendapatkan manfaat yang lebih besar dari investasi yang dikeluarkan.

http://www.antaranews.com/berita/477310/tiga-bidangusaha-pengguna-utama-big-data-di-indonesia, tanggal 30 Januari 2015, diakses tanggal 29 Agustus 2016.
Beberapa manfaat Big Data yang sudah dirasakan khususnya bagi dunia usaha diantaranya untuk mengetahui respons masyarakat terhadap produk-produk yang dikeluarkan melalui analisis sentimen di media sosial; membantu perusahaan mengambil keputusan secara lebih tepat dan akurat berdasarkan data; membantu meningkatkan citra perusahaan di mata pelanggan; untuk perencanaan usaha dengan mengetahui perilaku pelanggan, seperti pada perusahaan telekomunikasi dan perbankan; serta mengetahui tren pasar dan keinginan konsumen.

Selain bermanfat untuk analisis bisnis, teknologi Big Data juga dapat dimanfaatkan secara luas di pemerintahan. Beberapa peluang pemanfaatan Big Data di sektor publik antara lain untuk mendapatkan feedback dan respon masyarakat dari sistem informasi layanan pemerintah maupun dari media sosial, sebagai dasar penyusunan kebijakan dan perbaikan pelayanan publik; menemukan solusi atas permasalahan yang ada berdasarkan data, contohnya dengan menganalisa informasi cuaca dan tingkat kesuburan tanah, pemerintah dapat menetapkan atau menghimbau jenis varietas tanaman yang ditanam oleh petani pada daerah dan waktu tertentu; serta membantu dalam manajemen dan pengawasan keuangan negara.

Mengacu pada besarnya manfaat yang dapat ditawarkan oleh tren teknologi Big Data, khususnya di sektor publik, menarik untuk diteliti sejauh mana teknologi Big Data sudah dimanfaatkan di beberapa lembaga pemerintahan di Indonesia, dan tantangan apa saja yang muncul 
dalam penerapannya. Penerapan teknologi Big Data pada suatu lembaga dapat dilihat dari fungsifungsi yang sudah tersedia pada IT infrastrukturnya, sehingga dapat menjalankan kerja yang berhubungan dengan aplikasi mobile, social, dan Big Data-Analytic. Diharapkan hasil kajian dapat memberikan informasi dan inspirasi sehingga implementasi teknologi Big Data di Indonesia dapat semakin luas, khususnya di lembaga pemerintahan.

\section{METODE}

Penelitian ini menggunakan pendekatan kualitatif, dengan teknik pengumpulan data melalui wawancara mendalam kepada beberapa penanggungjawab atau pengelola teknologi informasi di 4 (empat) objek penelitian, yaitu Lembaga Kebijakan Pengadaan Barang/Jasa Pemerintah (LKPP), Pemerintah Kota Bandung, Direktorat Jenderal Pajak Kementerian Keuangan, dan Badan Informasi Geospasial (BIG), guna mendapatkan gambaran tentang pemanfaatan teknologi Big Data di instansi masing-masing, serta tantangan yang dihadapi dalam penerapannya. Namun demikian, implementasi Big Data di lembaga pemerintahan Indonesia tidak terbatas pada 4 (empat) lembaga yang disebutkan. Beberapa lembaga pemerintahan diluar objek penelitian, juga sudah menerapkan Big Data pada berbagai peruntukkan, seperti Pemerintah Provinsi DKI Jakarta dan Badan Pusat Statistik (BPS).
Selanjutnya, data dianalisis dengan menggunakan TDWI (The Data Warehousing Institute) Big Data Maturity Model, untuk mengevaluasi kematangan penerapan teknologi Big Data pada keempat instansi tersebut. Model kematangan TDWI dipilih dibandingkan dengan skala kematangan Big Data lainnya, seperti model Gartner atau Predictive Analytics Maturity Framework Assessment (PAMFA) dari Capgemini, dengan pertimbangan lebih mudah dipahami dan mengakomodir implementasi Big Data dari tahap persiapan hingga tahap matang/visioner.

\section{Penelitian Terdahulu}

Di level internasional, beberapa penelitian pernah dilakukan untuk mengukur status implementasi Big Data di beberapa organisasi. Salah satunya penelitian 'Big Data Survey', yang dilakukan oleh Capgemini Consulting pada tahun 2014 kepada 226 pimpinan perusahaan/organisasi global di kawasan Eropa, Amerika Utara dan AsiaPasifik. Hasil penelitian menemukan bahwa paling banyak (35\%) dari organisasi yang diteliti berada pada tahap partial production, dimana teknologi predictive analytics sudah diintegrasikan pada sebagian proses bisnis. Sementara lainnya berada pada tahap perencanaan konsep (29\%), belum diimplementasikan (24\%), dan hanya $13 \%$ yang sudah mencapai tahap pemanfaatan secara matang (Colas, 2014) 


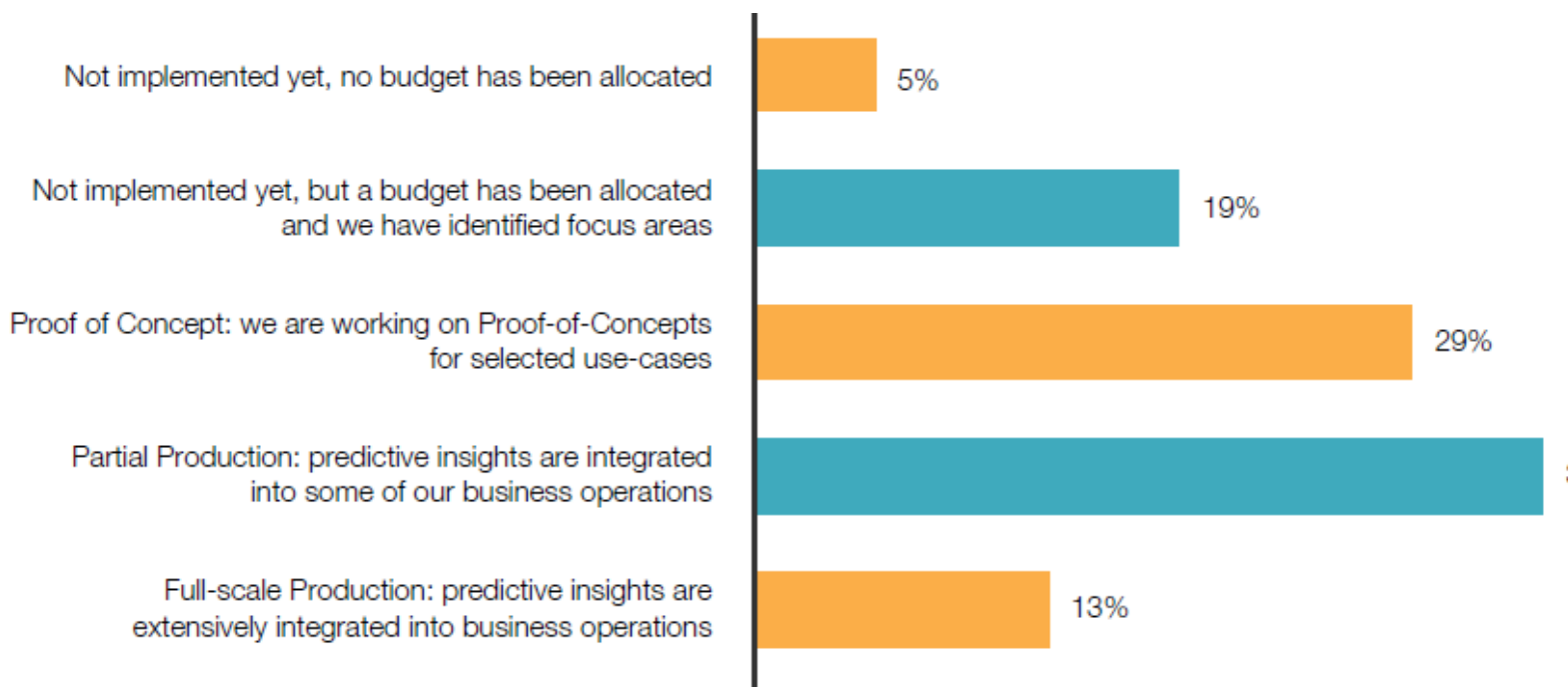

Gambar 1. Status implementasi teknologi Big Data di beberapa organisasi dunia (Sumber: 'Big Data Survey', Capgemini Consulting, 2014)

Pada level nasional, potensi penggunaan Big Data untuk layanan pemerintah di Indonesia pernah dikaji sebelumnya (Taufan, 2015). Dalam tulisan tersebut dikatakan bahwa pemerintah sebagai penyelenggara layanan publik memiliki peluang untuk menggunakan Big Data dalam beberapa proses layanan e-Government. Pengintegrasian data dan layanan adalah salah satu cara untuk memanfaatkan Big Data. Banyak sektor yang bisa disinergikan antara lain transportasi, pertanian, ketenaga-kerjaan, perkebunan, kelautan dan masih banyak lagi. Kajian tersebut juga memberikan benchmarking pemerintahan yang sudah menggunakan Big Data dalam beberapa layanan publik, seperti Jepang, Inggris, Taiwan, Thailand, dan Korea, namun sayangnya belum menggambarkan penggunaan Big Data pada pemerintahan di Indonesia.

Pembicaraan soal tantangan yang dihadapi dalam menerapkan Big Data dan kaitannya dengan kebijakan pembangunan di Indonesia pun masih sedikit ${ }^{2}$. Padahal, di masa depan kebijakan publik akan dibentuk oleh Big Data dan aplikasinya pada berbagai macam aspek kehidupan masyarakat seperti di sektor pendidikan, kesehatan, dan layanan publik lainnya.

\section{Konsep Big Data}

Istilah Big Data mulai muncul setelah Tahun 2005 diperkenalkan oleh O’Reilly Media. Namun sebenarnya penggunaan data dan kebutuhan untuk memahami data tersebut sebenarnya sudah ada sejak jaman dulu (Aryasa, 2015) Banyak pihak yang mencoba memberikan definisi terhadap Big Data (Chandarana, Parth, \& Vijayalakshmi, 2014) Dapat disimpulkan bahwa Big Data mengacu pada $3 \mathrm{~V}$ : volume, variety, velocity, dan ada yang menambahkan unsur V lainnya seperti veracity dan value. Volume (kapasitas data) berkaitan dengan

${ }^{2}$ https://m.tempo.co/read/news/2016/04/21/078764748/bigdata-akan-mewarnai-kebijakan-publik-di-indonesia, tanggal 21 April 2016, diakses tanggal 29 Agustus 2016. 
ukuran media penyimpanan data yang sangat besar atau mungkin tak terbatas hingga satuan petabytes atau zettabytes; variety (keragaman data) terkait tipe atau jenis data yang dapat diolah mulai dari data terstruktur hingga data tidak terstruktur; sedangkan velocity (kecepatan) terkait dengan kecepatan memroses data yang dihasilkan dari berbagai sumber, mulai dari data batch hingga real time, sementara karakteristik veracity (kebenaran) dan value (nilai) terkait dengan ketidakpastian data dan nilai manfaat dari informasi yang dihasilkan.

Pada Big Data, data terlalu besar dan terlalu cepat atau tidak sesuai dengan struktur arsitektur database konvensional. Sehingga untuk mendapatkan nilai dari data, harus digunakan teknologi untuk mengekstrak dan memperoleh informasi yang lebih spesifik.

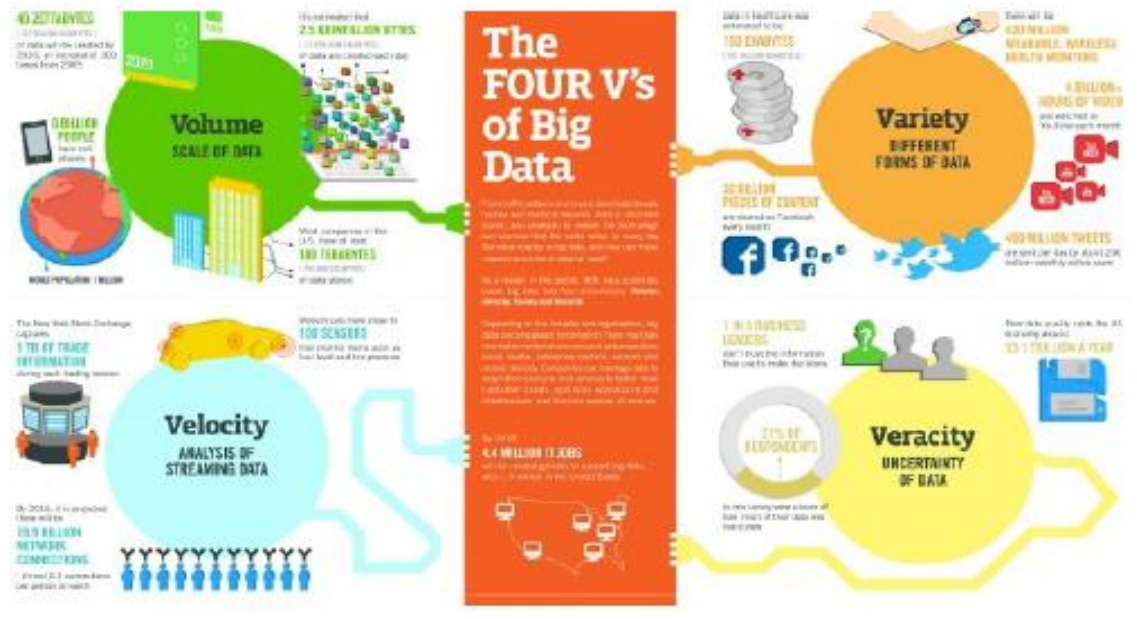

Gambar 2. 4V pada Big Data

(Sumber: http://www.ibmbigdatahub.com/infographic/four-vs-big-data)

Terminologi Big Data sering dikaitkan dengan data science, data mining, maupun data processing. Namun, Big Data melibatkan infrastruktur dan teknik data mining atau data processing yang lebih canggih dari sebelumnya. Dalam mengimplementasikan teknologi Big Data di suatu organisasi, ada 4 elemen penting yang menjadi tantangan, yaitu data, teknologi, proses, dan SDM (Aryasa, 2015)

- Data

Deskripsi dasar dari data menunjuk pada benda, event, aktivitas, dan transaksi yang terdokumentasi, terklasifikasi, dan tersimpan tetapi tidak terorganisasi untuk dapat memberikan suatu arti yang spesifik. Data yang telah terorganisir sehingga dapat memberikan arti dan nilai kepada penerima, disebut informasi. (Rainer, Kelly, \& Cegielski., 2009). Ketersediaan data menjadi kunci awal bagi teknologi Big Data. Ada beberapa organisasi yang memiliki banyak data dari proses bisnisnya yang dilakukan, baik data terstruktur maupun tidak terstruktur, seperti industri telekomunikasi maupun perbankan. Namun, ada pula organisasi yang perlu membeli atau bekerjasama dengan pihak lain untuk mendapatkan data. 


\section{- Teknologi}

Hal ini terkait dengan infrastruktur dan tools dalam pengoperasian Big Data, seperti teknik komputasi dan analitik, serta media penyimpanan (storage). Biasanya, organisasi tidak akan mengalami kendala yang berarti dalam hal teknologi karena teknologi bisa didapatkan dengan membeli atau kerjasama dengan pihak ketiga.

- Proses

Dalam proses mengadopsi teknologi Big Data dibutuhkan perubahan budaya organisasi. Misalnya, sebelum adanya Big Data, seorang pimpinan dalam menjalankan organisasi, melakukan pengambilan keputusan hanya berdasarkan 'intuisi' berdasarkan nilai, keyakinan atau asumsinya. Namun setelah adanya teknologi Big Data, pimpinan mampu bertindak "data-driven decision making" artinya mengambil keputusan berdasarkan data yang akurat dan informasi yang relevan. Contoh lain, sebuah perusahan telekomunikasi sejak menggunakan sistem monitoring informasi digital yang berasal dari web, twitter, dan lain-lain, dapat dengan lebih mudah mengetahui masalah pelanggan terkait produk dan membangun komitmen untuk menindaklanjuti masalah tersebut dalam paling lama 6 jam. Dalam hal ini terbangun budaya organisasi baru tentang brand tracking, untuk menyikapi kecenderungan pelanggan yang dewasa ini lebih memilih membicarakan suatu masalah di twitter dibandingkan mengajukan komplain langsung ke customer service. Big Data dapat membantu untuk melakukan analisis dan prediksi terhadap pelanggan yang akan menghentikan layanannya atau churn, sehingga dapat ditindaklanjuti dengan mendengarkan kebutuhan pelanggan serta melakukan pencegahan di awal.

- SDM

Dalam mengaplikasikan teknologi Big Data dibutuhkan SDM dengan keahlian analitik dan kreativitas yaitu kemampuan/keterampilan untuk menentukan metode baru yang dapat dilakukan untuk mengumpulkan, menginterpretasi dan menganalisis data, keahlian pemrograman komputer, dan ketrampilan bisnis yaitu pemahaman tentang tujuan bisnis.

Sumber data dalam teknologi Big Data dapat berupa data terstruktur dan tidak terstruktur. Data terstruktur memiliki tipe data, format, dan struktur yang telah terdefinisi. Data dapat berupa data transaksional, OLAP data, tradisional RDBMS, file CSV, spread-sheets sederhana. Sementara data tidak terstruktur merupakan data tekstual dengan format tidak menentu atau tidak memiliki struktur melekat, sehingga untuk menjadikannya data terstruktur membutuhkan usaha, tools, dan waktu yang lebih. Data ini dihasilkan oleh aplikasiaplikasi internet, seperti data URL log, media sosial, e-mail, blog, video, audio serta data semantik.

Sejak dikenalnya Big Data dalam pengumpulan dan analisis data, teknik ini mulai diperbandingkan dengan metode konvensional yang sebelumnya dilakukan, seperti survei. Masing-masing metode memiliki kekurangan dan kelebihan masing-masing, dengan perbandingan seperti terlihat pada Tabel 1 . 
Tabel 1. Perbandingan metode konvensional vs data analitik dalam pengumpulan dan analisis data.

\begin{tabular}{ll}
\hline \multicolumn{1}{c}{ LEGACY } & \multicolumn{1}{c}{ DATA ANALYTICS } \\
\hline Confirmative & Explorative (predictive) \\
\hline Small data set & Large data set \\
\hline Small number of variable & Large number of variable \\
\hline Deductive (no predictions) & Inductive \\
\hline Numeric data & Numeric and non-numeric data \\
\hline Clean data & Data cleaning \\
\hline
\end{tabular}

Sumber: (Friedman, 1997)

\section{Tools Big Data}

Beberapa tools yang tersedia untuk penerapan Big Data dapat dikategorikan menjadi 2, berbayar (personalized software) dan tidak berbayar (berbasis open source software). Tools tersebut berkaitan dengan 4 (empat) tahapan aktivitas dan dukungan teknologi pada Big Data yang mencakup (Alamsyah, 2015):

- Acquired, berhubungan dengan sumber dan cara mendapatkan data.

- Accessed, berhubungan dengan daya akses data. Data yang sudah dikumpulkan memerlukan tata kelola, integrasi, storage dan computing agar dapat dikelola untuk tahap berikutnya. Beberapa processing/computing tools yang digunakan seperti: Hadoop, Nvidia CUDA, twitter storm, GraphLab, sementara beberapa tools terkait storage antara lain: neo4J, Titan, HDFS.

- Analytic, berhubungan dengan informasi yang akan didapatkan, atau hasil pengelolaan data yang telah diproses. Analitik yang dilakukan dapat berupa descriptive (penggambaran data), diagnostic (mencari sebab akibat berdasar data), predictive (memprediksi kejadian dimasa depan) maupun prescriptive analytics (merekomendasikan pilihan dan implikasi dari setiap opsi). Beberapa analytics tools yang digunakan seperti: MLPACK, Mahout, R. Perangkat lunak (software) R paling banyak digunakan karena berbasis open source dan memiliki keunggulan pada pendekatan analisis data menggunakan visualisasi untuk menemukan karakteristik yang penting dari suatu dataset.

- Application terkait visualisasi dan reporting hasil dari analitik. Contoh application tool yang digunakan pada tahap ini yaitu RStudio.

Untuk perangkat lunak berbayar (proprietary software) yang mendukung Big Data analytics, hal ini menjadi model bisnis baru bagi beberapa vendor/perusahaan dengan menawarkan Big Data untuk menunjang pertumbuhan di industri lain. Seperti pada sebuah perusahaan telekomunikasi, yang menjadi penyedia jasa data analitik bagi beberapa instansi/lembaga pemerintah pusat dan daerah, industri penerbangan, dan kesehatan. Kelebihan operator telekomunikasi terletak pada memiliki dan mengelola data pelanggan yang sangat banyak seperti data transaksi, data lokasi serta data kunjungan ke website, sehingga melalui data tersebut, dilengkapi dengan sumber data 
lainnya, dapat dilakukan data analitik. Sebagai contoh, dengan jumlah pelanggan 156 juta orang, diketahui bahwa dalam satu menit terjadi kicauan di Twitter sebanyak 98 ribu, update status di Facebook sebanyak 695 ribu, serta pembicaaan di instant messaging sebanyak 11 juta. Data ini dapat bercerita banyak hal jika diolah. Selain itu, ada pula vendor/perusahaan yang secara spesifik bergerak di bidang IT solution yang menyediakan solusi berbasis teknologi Big Data sesuai dengan kebutuhan klien (personilized). Ada vendor yang membuat tool analytic secara parsial, misalnya tool untuk integrasi data saja, penyimpanan data, analitis data, dan presentasi data hasil analisis. Tetapi ada pula vendor yang menyediakan tool secara lengkap, mulai dari integrasi data sampai analitis dan presentasi data. Vendor-vendor tersebut ada yang merupakan perusahaan besar di bidang TI, namun banyak pula yang merupakan perusahaan pemula milik anak bangsa.

\section{TDWI Big Data Maturity Model}

Kematangan penerapan Big Data dimaksudkan untuk menunjukkan proses evolusi yang dilakukan oleh sebuah organisasi dalam mengintegrasikan, mengelola, dan memanfaatkan semua sumber data yang relevan baik internal dan eksternal. Hal ini mencakup menciptakan ekosistem yang inovatif, memberikan nilai bisnis yang bermanfaat, dan memungkinkan transformasi yang berdampak. Dengan kata lain, kematangan penerapan Big Data tidak hanya tentang memiliki beberapa teknologi untuk menangani data bervolume tinggi atau hanya tentang menggunakan media sosial untuk menganalisis opini publik, tetapi sebuah proses yang melibatkan pembangunan ekosistem yang mencakup teknologi, manajemen data, analisis, pengaturan, dan komponen organisasi (Halper, Fern, \& Krishnan, 2013).

Model kematangan Big Data versi TDWI terdiri dari 5 tahapan: nascent, pre-adoption, early adoption, corporate adoption, dan maturel visionary (Gambar 3), dan melihat pada 5 dimensi, yaitu: Organisasi, Infrastruktur, Manajemen Data, Analitik, dan Governance. Penjelasan untuk tiap tahapan yaitu sebagai berikut:

Tahap 1: nascent, pada tahap ini, umumnya organisasi memiliki awareness yang rendah terhadap teknologi Big Data dan nilai manfaatnya bagi organisasi.

Tahap 2: pre-adoption, pada tahap ini organisasi mulai mempersiapkan langkah terkait Big Data analitik dan akan mengimplementasikannya dalam waktu dekat. Beberapa SDM sudah mulai mempelajari tentang Big Data dan organisasi sudah menginvestasikan tools pendukung Big Data, seperti Hadoop, namun ruang lingkupnya masih parsial.

Tahap 3: early-adoption, tahap ini ditandai dengan adanya beberapa konsep-konsep (Proof of Concept/POC) implementasi yang mulai/sudah diujicoba. Organisasi biasanya menghabiskan waktu yang lebih lama pada tahap ini, karena terdapat gap yang cukup jauh untuk mencapai level selanjutnya, corporate adoption.

Tahap 4: corporate adoption, pada tahap ini end users telah dilibatkan, mendapatkan wawasan 
dan mentransformasi proses kerjanya. Keputusan dalam organisasi diambil menggunakan Big Data analitik.

Tahap 5: mature/visionary, pada tahap ini organisasi melaksanakan program Big Data sebagai suatu mesin yang ditunjang dengan infrastruktur yang memadai, perencanaan dan strategi yang matang dan pembiayaan yang cukup.

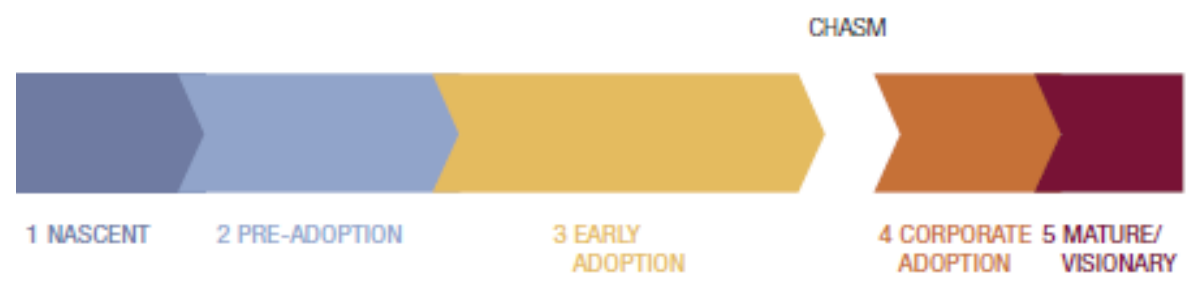

Gambar 3. Tahapan kematangan pada TDWI Big Data Maturity Model Sumber: (Halper et al., 2013)

Tabel 2. Ringkasan indikator dimensi pada tiap level kematangan TDWI Big Data Maturity Model

\begin{tabular}{|c|c|c|c|c|c|}
\hline DimensilTahap & Nascent & Pre-adoption & Early-adoption & $\begin{array}{c}\text { Corporate } \\
\text { adoption }\end{array}$ & Mature/visionary \\
\hline Organization & $\begin{array}{l}\text { Has not yet } \\
\text { started to } \\
\text { explore } \\
\text { advanced } \\
\text { analytics or } \\
\text { begun its big } \\
\text { data journey. }\end{array}$ & $\begin{array}{l}\text { The mindset is } \\
\text { generally } \\
\text { around } \\
\text { experimentation. } \\
\text { The team is } \\
\text { trying to } \\
\text { determine the } \\
\text { top business } \\
\text { problems to } \\
\text { solve. }\end{array}$ & $\begin{array}{l}\text { Gets excited } \\
\text { about the } \\
\text { prospects of big } \\
\text { data, more } \\
\text { people start to } \\
\text { come on board. }\end{array}$ & $\begin{array}{l}\text { Realize that } \\
\text { analytics is a } \\
\text { competitive } \\
\text { differentiator, } \\
\text { Innovation in } \\
\text { data and data } \\
\text { analysis is a } \\
\text { core value, and } \\
\text { an analytics } \\
\text { culture prevails. }\end{array}$ & $\begin{array}{l}\text { Executives view } \\
\text { big data } \\
\text { analytics as } \\
\text { critical and } \\
\text { standard for how } \\
\text { to do business, } \\
\text { continuously } \\
\text { determining new } \\
\text { ways to use and } \\
\text { create value from } \\
\text { analytics, } \\
\text { collaboration } \\
\text { becomes culture. }\end{array}$ \\
\hline Infrastructure & $\begin{array}{l}\text { No specific } \\
\text { infrastructure to } \\
\text { support critical } \\
\text { big data } \\
\text { components. }\end{array}$ & $\begin{array}{l}\text { May be trying } \\
\text { out Hadoop or } \\
\text { some other } \\
\text { big data } \\
\text { technologies as } \\
\text { part of the } \\
\text { experimentation. }\end{array}$ & $\begin{array}{l}\text { There may be } \\
\text { various kinds of } \\
\text { big data } \\
\text { technology in } \\
\text { place, typical ly } \\
\text { a tier } 2 \\
\text { production-class } \\
\text { cluster that is } \\
\text { installed and } \\
\text { maintained in } \\
\text { the company's } \\
\text { data center or } \\
\text { even in the } \\
\text { cloud. }\end{array}$ & $\begin{array}{l}\text { Typically a tier } \\
1 \text { production- } \\
\text { class cluster. } \\
\text { The information } \\
\text { architecture is } \\
\text { unified that } \\
\text { underpins the } \\
\text { analytics, can } \\
\text { perform multiple } \\
\text { workloads on a } \\
\text { cluster, comply } \\
\text { with backup and } \\
\text { recovery or } \\
\text { disaster } \\
\text { recovery } \\
\text { procedures. }\end{array}$ & $\begin{array}{l}\text { Deployed } \\
\text { coherent } \\
\text { analytics } \\
\text { infrastructure, } \\
\text { able to integrate } \\
\text { new sources of } \\
\text { data for } \\
\text { analytics, there is } \\
\text { security, disaster } \\
\text { recovery, backup } \\
\text { and recovery, } \\
\text { performance } \\
\text { management, and } \\
\text { proactive } \\
\text { infrastructure } \\
\text { monitoring. }\end{array}$ \\
\hline $\begin{array}{c}\text { Data } \\
\text { management }\end{array}$ & $\begin{array}{l}\text { Having some } \\
\text { sort of data } \\
\text { warehouse. But } \\
\text { its data strategy } \\
\text { and data life }\end{array}$ & $\begin{array}{l}\text { May have } \\
\text { started to } \\
\text { identify and } \\
\text { collect some big } \\
\text { data sources. }\end{array}$ & $\begin{array}{l}\text { Have data } \\
\text { collected as files } \\
\text { of different } \\
\text { formats, } \\
\text { potentially with }\end{array}$ & $\begin{array}{l}\text { Make use many } \\
\text { forms of data, } \\
\text { well managed } \\
\text { data sharing, } \\
\text { has metadata }\end{array}$ & $\begin{array}{l}\text { Can manage } \\
\text { complexity, data } \\
\text { is shared across } \\
\text { the organization. }\end{array}$ \\
\hline
\end{tabular}




\begin{tabular}{|c|c|c|c|c|c|}
\hline DimensilTahap & Nascent & Pre-adoption & Early-adoption & $\begin{array}{c}\text { Corporate } \\
\text { adoption }\end{array}$ & Mature/visionary \\
\hline & $\begin{array}{l}\text { cycle } \\
\text { management } \\
\text { strategy are not } \\
\text { strong. }\end{array}$ & & $\begin{array}{l}\text { division or } \\
\text { enterprise } \\
\text { standards for } \\
\text { naming and } \\
\text { storage } \\
\text { management. }\end{array}$ & $\begin{array}{l}\text { and defined end } \\
\text { state data } \\
\text { architecture, } \\
\text { defined data life } \\
\text { cycle } \\
\text { management } \\
\text { and data } \\
\text { auditability. }\end{array}$ & \\
\hline Analytics & $\begin{array}{l}\text { Typically, if the } \\
\text { organization has } \\
\text { utilizing } \\
\text { advanced } \\
\text { analytics such } \\
\text { as predictive } \\
\text { analytics, it is } \\
\text { working with } \\
\text { structured data } \\
\text { only. }\end{array}$ & $\begin{array}{l}\text { Has explored } \\
\text { some kind of } \\
\text { advanced } \\
\text { analytics. }\end{array}$ & $\begin{array}{l}\text { May be utilizing } \\
\text { descriptive or } \\
\text { even predictive } \\
\text { analytics, } \\
\text { depend on the } \\
\text { problem to } \\
\text { solve. }\end{array}$ & $\begin{array}{l}\text { New data } \\
\text { coming can be } \\
\text { analyzed quickly } \\
\text { and made part } \\
\text { of the logical } \\
\text { infrastructure, } \\
\text { analytics } \\
\text { supports the } \\
\text { organization., } \\
\text { has center of } \\
\text { excellence } \\
\text { (COE) that } \\
\text { serves diff erent } \\
\text { parts of the } \\
\text { organization. }\end{array}$ & $\begin{array}{l}\text { Makes use of all } \\
\text { kinds of data, } \\
\text { including real- } \\
\text { time data, and } \\
\text { uses this as part } \\
\text { of its decision } \\
\text { making and } \\
\text { incorporates into } \\
\text { business } \\
\text { processes. }\end{array}$ \\
\hline Governance & $\begin{array}{l}\text { Governance } \\
\text { strategy is more } \\
\text { IT centric than } \\
\text { business-and-IT } \\
\text { centric. }\end{array}$ & $\begin{array}{l}\text { Have a steering } \\
\text { committee } \\
\text { overseeing the } \\
\text { program from a } \\
\text { governance } \\
\text { perspective. }\end{array}$ & $\begin{array}{l}\text { Have corporate } \\
\text { sponsorship and } \\
\text { infrastructure, } \\
\text { but yet settle } \\
\text { governance } \\
\text { team. }\end{array}$ & $\begin{array}{l}\text { Have program } \\
\text { governance with } \\
\text { PMO and } \\
\text { steering } \\
\text { committee, } \\
\text { executed } \\
\text { program as } \\
\text { budgeted and } \\
\text { planned } \\
\text { enterprise } \\
\text { initiative. }\end{array}$ & $\begin{array}{l}\text { The program is } \\
\text { treated as } \\
\text { mission critical } \\
\text { and given the } \\
\text { right amount of } \\
\text { staffing and } \\
\text { skills. }\end{array}$ \\
\hline
\end{tabular}

Sumber: (Halper et al., 2013)

Adapun kondisi untuk kelima dimensi pada masing-masing tahap kematangan Big Data seperti dijelaskan pada Tabel 2 diatas, dimana untuk menilai kematangan Big Data pada suatu organisasi, TDWI telah mengembangkan instrument pengukuran berdasarkan faktor-faktor seperti ditunjukkan pada Gambar 4, yang terdiri dari 50 pertanyaan indikator, masing-masing dimensi dijelaskan oleh 10 pertanyaan indikator. Namun, karena pengumpulan data yang dilakukan dalam penelitian ini berupa data kualitatif dan bukan kuantitatif melalui survei, maka penilaian kematangan Big Data versi TDWI tidak dapat diaplikasikan secara rigid, hanya mengacu pada tahapan kematangannya saja. 


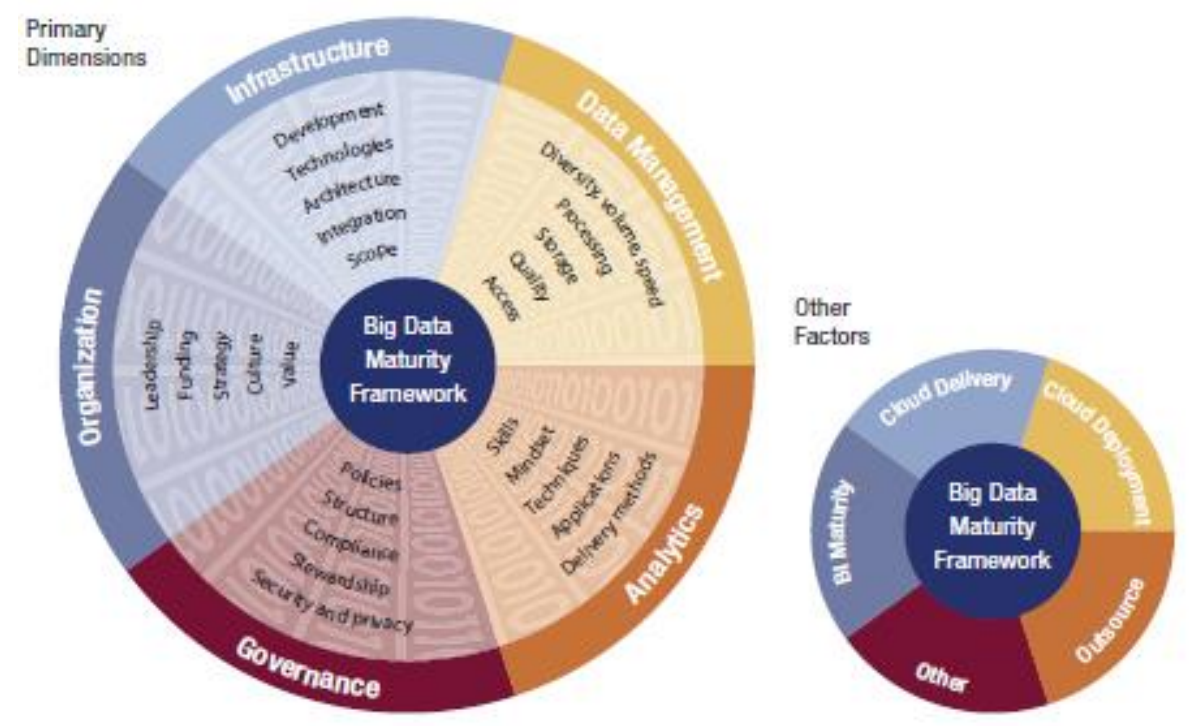

Gambar 4. TDWI Big Data Maturity Assessment Criteria

Sumber: (Halper et al., 2013)

\section{HASIL DAN PEMBAHASAN}

\section{Deskripsi Penerapan Teknologi Big Data di Lembaga Pemerintahan}

Sejak meluasnya penggunaan teknologi Big Data di Indonesia di sekitar tahun 2013, banyak sektor private yang telah memanfaatkan teknologi tersebut untuk mengembangkan bisnisnya. Sementara penerapannya di sektor publik/pemerintahan, tampaknya masih terbatas.

Berdasarkan hasil pengumpulan data di lapangan, akan dipaparkan dan dianalisis implementasi teknologi Big Data di 4 (empat) instansi/kementerian/lembaga yang telah menginisiasi dan memanfaatkan Big Data pada proses bisnisnya. Namun demikian, tidak berarti implementasi Big Data di Indonesia baru sebatas pada empat lembaga yang disebutkan. Penulis yakin banyak lembaga pemerintahan lainnya yang juga sudah menerapkan Big Data dalam berbagai peruntukkan, seperti Pemerintah Provinsi DKI Jakarta dan Badan Pusat Statistik (BPS). Namun karena keterbatasan pengumpulan data yang dilakukan, hanya empat lembaga yang termasuk dalam objek penelitian ini.

1. Lembaga Kebijakan Pengadaan Barang/Jasa Pemerintah (LKPP)

Sebagai lembaga yang bertugas melaksanakan pengembangan, perumusan, dan penetapan kebijakan Pengadaan Barang/Jasa Pemerintah, LKPP telah melakukan inovasi berbasis teknologi informasi untuk dapat memfasilitasi sistem Layanan Pengadaan Secara Elektronik (LPSE) di semua Kementerian/Lembaga/Daerah. Dari 630 LPSE yang ada di seluruh Indonesia, 90\% sudah terintegrasi dengan teknologi cloud LKPP sehingga seluruh database, file, dan aplikasi di LPSE dapat di-backup.

Selain itu, sejak tahun 2014 LKPP telah merencanakan penggunaan teknologi Big Data dan 
akan siap diimplemetasikan di tahun 2016. Aplikasi perdana yang dibangun bertujuan memantau availability dan capacity dari LPSELPSE di Kementerian/Lembaga/Daerah, dengan software bernama SPLUNK. Software ini dibuat oleh pihak ketiga (PT. Global Innovation) dengan budget sebesar 6 Miliar untuk kapasitas 125 GB dan prinsip perpetual, artinya software tersebut menjadi milik pembeli dan dapat digunakan seterusnya tanpa perpanjangan atau update. Disamping menggunakan jasa pihak ketiga, LKPP juga telah mengalokasikan biaya untuk membangun sendiri software tambahan berbasis Big Data. Harapannya, dengan teknologi Big Data, LKPP dapat memonitor LPSE di seluruh Indonesia dengan system alert untuk warning, security, atau capacity overload, serta menyediakan data informasi tentang perkembangan (progress) pengadaan disetiap LPSE. Namun demikian, pengembangan software tambahan tersebut menghadapi kendala bahwa jika menggunakan open source diperlukan riset pendahuluan yang cukup memakan waktu sehingga dikhawatirkan tidak cukup untuk mengejar pertumbuhan LPSE.

\section{Pemerintah Kota Bandung}

Pemerintah Kota Bandung, dibawah pimpinan Walikota Ridwan Kamil, melakukan terobosan baru berbasis teknologi informasi dengan membangun Digital Command Center di tahun 2015. Fasilitas ini terletak dikawasan Balai Kota Bandung dan beroperasi dibawah wewenang Dinas Komunikasi dan Informatika.

Beragam aplikasi tersedia di command center tersebut, seperti akses data/informasi kunci dari 34
Satuan Kerja Perangkat Daerah (SKPD) dan 30 kecamatan untuk menampilkan laporan kinerja masing-masing instansi atau transparansi proses pengadaan barang/jasa yang dilakukan. Selain itu, monitoring CCTV yang tersebar di beberapa titik di kota Bandung untuk memantau dan mengatasi dengan cepat kejadian di lapangan semisal kemacetan/kebakaran. Selanjutnya Integrated Operation Center yaitu sistem notifikasi otomatis sesuai Standard Operating System (SOP) misalnya SOP penanganan kebakaran atau SOP pengamanan demonstrasil; serta GPS tracking terhadap kendaraan dinas seperti mobil pemadam kebakaran dan ambulans. Adapula aplikasi panic button yang merupakan pertolongan kondisi darurat (emergency) bagi penduduk Bandung. Command center milik Pemkot Bandung ini beroperasi 24 jam,dengan dukungan 5 orang pegawai dan 8 orang tenaga honorer.

Diantara aplikasi-aplikasi tersebut, yang berbasis teknologi Big Data yaitu social media analytics. Social media analytic menyajikan data trending topic dan analisis tentang Kota Bandung yang diperoleh dari sosial media (facebook dan twitter). Layanan ini akan mendukung Pemkot Bandung untuk mengetahui topik terhangat yang dibahas oleh masyarakat Bandung saat ini dan membantu memetakan masalah di setiap kecamatan. Dengan demikian, pemerintah dapat melakukan evaluasi terhadap program dan kebijakannya berdasarkan respon masyarakat dan memudahkan pengambilan keputusan. Aplikasi ini merupakan hibah dari Norwegia, yang dikembangkan lebih lanjut oleh vendor lokal. 


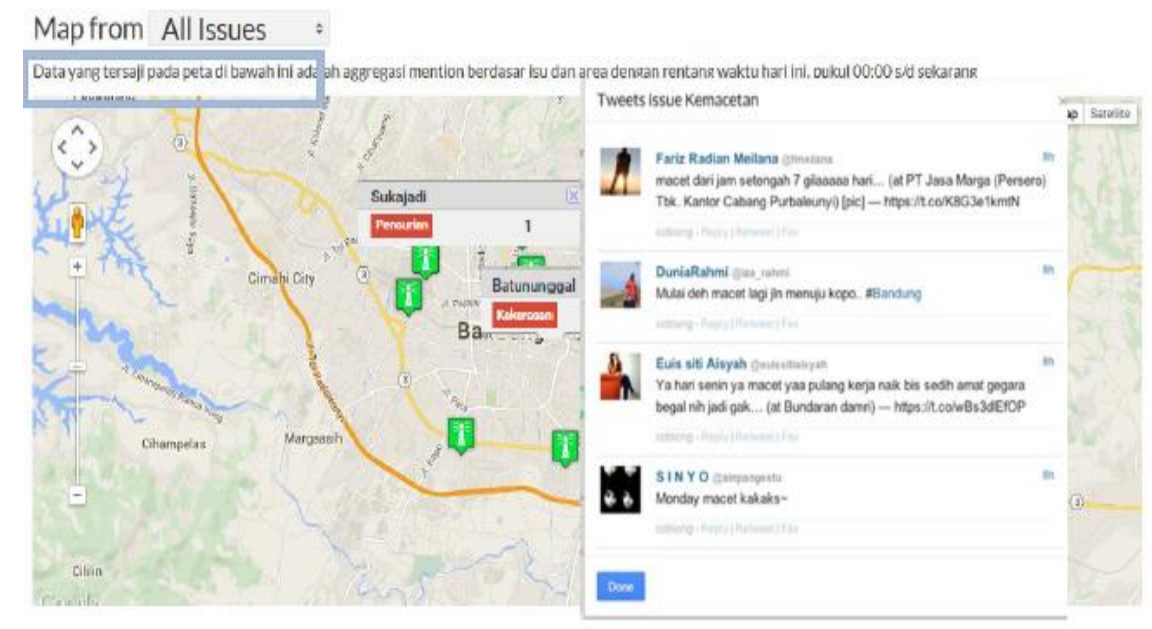

Gambar 5. Tweet map untuk memonitor isu publik terkini di kota Bandung Sumber: (Aryasa, 2015)

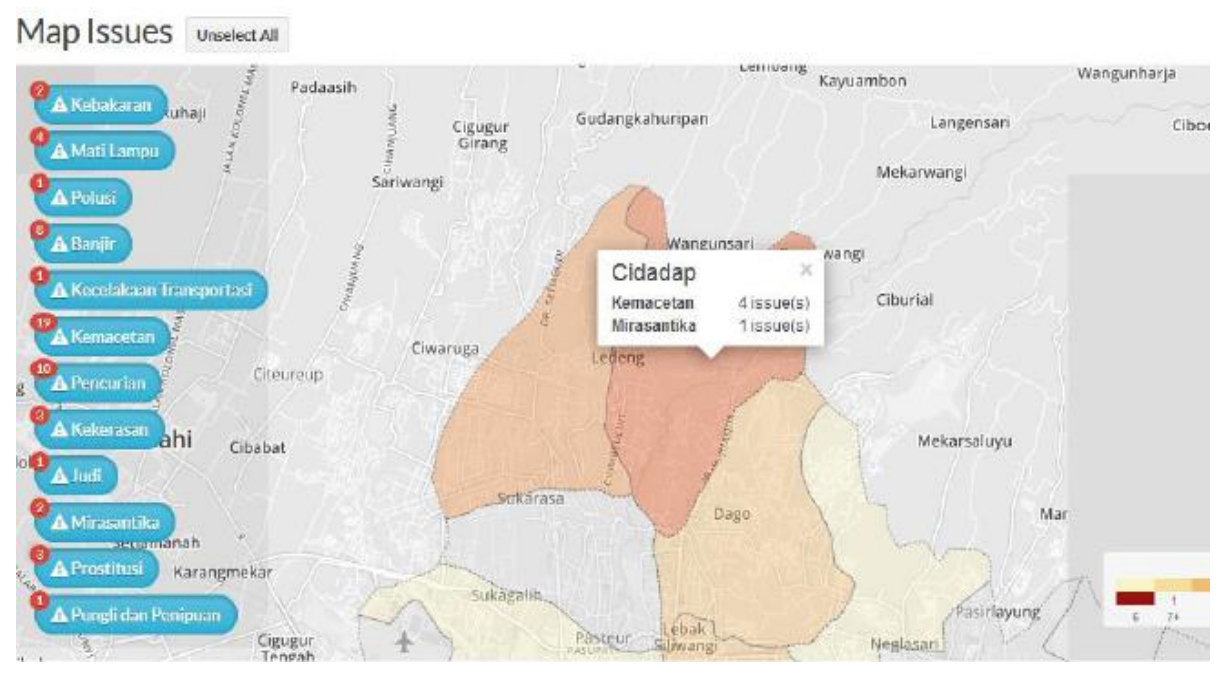

Gambar 6. Tweet map berdasarkan kategori isu di kota Bandung Sumber: (Aryasa, 2015)

3. Direktorat Jenderal Pajak, Kementerian rekening tabungan ${ }^{3}$. Hal tersebut membutuhkan

Keuangan

Ditjen Pajak mencoba mengoptimalkan pemanfaatan teknologi informasi untuk meningkatkan penerimaan negara dan memerangi kecurangan terkait pajak. Salah satunya rencana menggali data lewat media sosial untuk dicocokkan dengan laporan pajak dan data dukungan teknologi Big Data.

Berdasarkan pengalaman Ditjen Pajak menuju implementasi Big Data, Direktur Transformasi TIK Ditjen Pajak, Ir. Iwan Djuniardi, MM.

3 http://nasional.kontan.co.id/news/ditjen-pajak-menggalidata-lewat-media-sosial, tanggal 12 Oktober 2015, diakses 15 November 2015. 
menjelaskan bahwa terobosan dimulai dengan menyediakan 10 PC, menjalin kerjasama dengan komunitas, menggunakan aplikasi open source, serta pengadaan satu cluster enterprise datawarehouse, satu cluster Hadoop untuk integrasi data, dan satu cluster Hadoop untuk platform data. Contoh hasil sementara use case yang didapat yaitu:

$>$ Analisa Central Tax Analysis: ditemukan 3.563 kasus senilai 32, 7 Trilyun

$>$ Penerbitan faktur tidak berdasarkan transaksi sebenarnya: ditemukan 21.123 kasus senilai

6,2 Trilyun
Penerbitan faktur pajak ganda: dengan menggunakan Hadoop cluster 10 pc, dapat selesai dalam 9 jam, lebih cepat dibanding menggunakan RDBMS yang memakan waktu 3 hari lebih, terhadap 1,77 milyar data faktur.

Ditjen Pajak akan terus mengeksplorasi penggunaan teknologi Big Data karena sudah menjadi kebutuhan. Di saat bersamaan diperlukan perbaikan aturan dan pengadopsian proses bisnis "out-of-box" untuk membuatnya berhasil (Djuniardi, 2015)

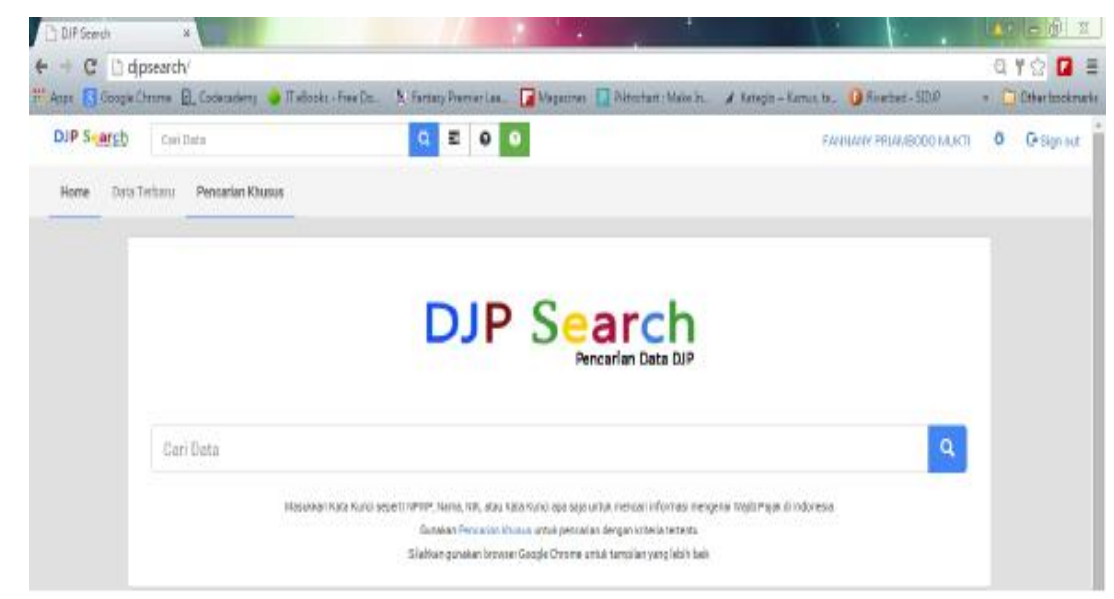

Gambar 7. Tampilan Mesin Pencari Data Ditjen Pajak untuk mencari informasi mengenai wajib pajak di Indonesia (Sumber: Djuniardi, 2015)

\section{Badan Informasi Geospasial (BIG)}

Dengan adanya Undang-Undang No. 4/2011 tentang Informasi Geospasial dan Perpres No. 27/2014 tentang Jaringan Informasi Geospasial Nasional (JIGN) yang mengamanatkan kebijakan satu peta (one map policy), Badan Informasi Geospasial diharapkan menjadi referensi tunggal untuk informasi geospasial. Dengan demikian, lembaga ini menjadi basis dan pengelola data ruang kebumian yang berukuran sangat besar. Data ruang kebumian mengacu pada lokasi, letak, dan posisi suatu objek atau kejadian yang berada dibawah, pada, atau diatas permukaan bumi dalam sistem koordinat tertentu.

Elemen geospasial (lokasi) dari sebuah informasi digunakan sebagai identifier utama (core identifier) untuk mengintegrasikan berbagai jenis informasi, sehingga data tersebut akan dibuat 
terbuka untuk memungkinkan berbagi pakai data dan informasi geospasial bagi kepentingan semua sektor. Sembilan puluh persen aktifitas kepemerintahan memiliki elemen spasial, sehingga diperlukan kesamaan gerak antar instansi. Implikasi yang diharapkan adalah seluruh data dan informasi dapat dengan mudah diintegrasikan untuk memecahkan masalah secara komprehensif, lebih cepat dan lebih baik, serta menghasilkan berbagai macam analisis yang lebih tajam dan komprehensif.

Peran Data dan Informasi Geospasial sangat signifikan (Khafid, 2015) yaitu:

$\checkmark$ Pengambilan keputusan yang efisien dan efektif memerlukan informasi spasial maupun non-spasial yang up-to-date dan akurat, yang menjelaskan situasi terkini yg terjadi.

$\checkmark \quad$ Tidak satupun institusi yang memiliki data dan informasi lengkap untuk keperluan pengambilan keputusan di berbagai sektor, sehingga data sharing merupakan sebuah keharusan.

$\checkmark$ Diperlukan pengaturan dan penggunaan teknologi yang tepat untuk mengatasi permasalahan akses terhadap informasi geospasial untuk mendukung proses pengambilan keputusan yang efisien dan efektif, maka dibangunlah geoSpatial Data Infrastructure (SDI).

Adapun manfaat dari 'sharing' Informasi GeoSpasial, yaitu:

$\checkmark$ Menghindari duplikasi dalam penyediaan data dan informasi geospasial

$\checkmark$ Meningkatkan kualitas dan meredusir harga data dan informasi spasial

$\checkmark$ Menjadikan data dan informasi geospasial mudah diakses oleh pihak yang memerlukan

$\checkmark \quad$ Membangun kemitraan antar berbagai institusi untuk meningkatkan ketersediaan data dan informasi.

Badan Informasi Geospasial telah mengantisipasi penggunaan Big Data dalam mengelola data melalui penyediaan kapasitas storage hingga 2 petabytes, menggunakan high performance computing (HPC) dan geoprocessing, serta memanfaatkan cloud computing. Data yang harus diolah mencakup data citra, GPS, foto udara, peta tematik, pasut, yang sebagian diterima secara real time melalui sistem TEWS (tsunami early warning system), aplikasi pemetaan partisipatif, maupun Geoportal, yaitu jaringan data spasial digital berbasis web (Khafid, 2015). 


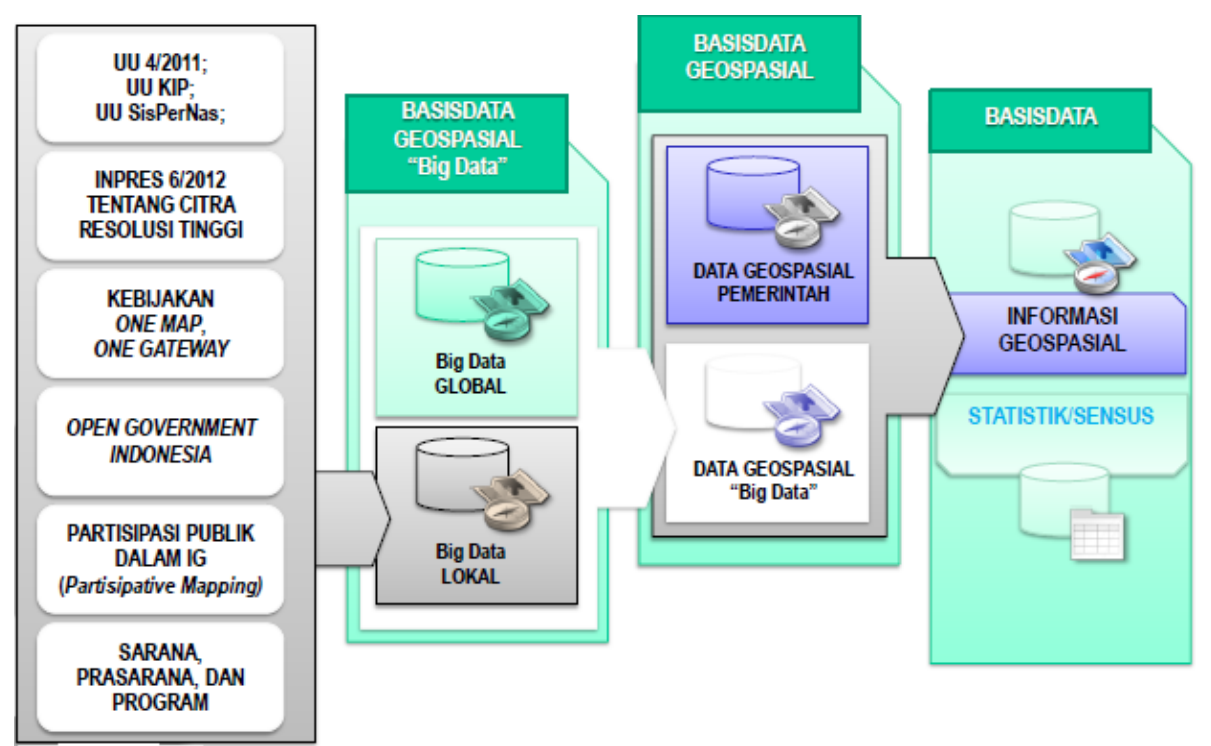

Gambar 8. Pengelolaan Informasi Geospasial untuk pembangunan berkelanjutan Sumber: (Khafid, 2015)

Analisis Penerapan Teknologi Big Data di Empat Lembaga

Selanjutnya, deskripsi kualitatif diatas akan dianalisis dengan kerangka analisis TDWI Big Data Maturity Model untuk mengetahui level kematangan penerapan teknologi Big Data di keempat instansi tersebut. Status kematangan dapat dicirikan dari indikator-indikator pada lima dimensi yang mencakup: organisasi, infrastruktur, manajemen data, analitik, dan tata kelola, sehingga nantinya dapat disimpulkan apakah penerapan teknologi Big Data di keempat instansi tersebut berada pada tahap nascent, pre-adoption, early adoption, corporate adoption, atau mature/visionary.

Tabel 3. Identifikasi indikator pendukung implementasi big data di empat objek penelitian

\begin{tabular}{|c|c|c|c|c|c|}
\hline Dimensi & Indikator & LKPP & $\begin{array}{l}\text { Pemkot } \\
\text { Bandung }\end{array}$ & $\begin{array}{l}\text { Ditjen } \\
\text { Pajak }\end{array}$ & BIG \\
\hline \multirow[t]{5}{*}{ Organisasi } & Kepemimpinan & & $\mathrm{V}$ & $\mathrm{V}$ & $\mathrm{V}$ \\
\hline & Pembiayaan & $\mathrm{v}$ & $\mathrm{v}$ & & $\mathrm{v}$ \\
\hline & Strategi & & $\mathrm{v}$ & & \\
\hline & Budaya & & & & \\
\hline & Nilai (value) & $\mathrm{v}$ & $\mathrm{v}$ & $\mathrm{v}$ & \\
\hline \multirow[t]{5}{*}{ Infrastruktur } & Pengembangan & & & & \\
\hline & Teknologi & $\mathrm{v}$ & $\mathrm{v}$ & $\mathrm{v}$ & $\mathrm{v}$ \\
\hline & Arsitektur & & & & \\
\hline & Integrasi & & $\mathrm{v}$ & & $\mathrm{v}$ \\
\hline & Lingkup (scope) & $\mathrm{v}$ & $\mathrm{v}$ & & $\mathrm{v}$ \\
\hline
\end{tabular}




\begin{tabular}{|c|c|c|c|c|c|}
\hline \multirow[t]{4}{*}{ Manajemen data } & $\begin{array}{l}\text { Keragaman, } \\
\text { kecepatan } \\
\text { Pemrosesan }\end{array}$ & & $\mathrm{v}$ & $\mathrm{v}$ & $\mathrm{v}$ \\
\hline & Penyimpanan & $\mathrm{v}$ & $\mathrm{v}$ & & $\mathrm{v}$ \\
\hline & Kualitas & & $\mathrm{v}$ & & \\
\hline & Akses & $\mathrm{v}$ & $\mathrm{v}$ & & $\mathrm{v}$ \\
\hline \multirow[t]{5}{*}{ Analitik } & Kemampuan SDM & & & & \\
\hline & Pola pikir (mindset) & $\mathrm{v}$ & $\mathrm{v}$ & $\mathrm{v}$ & $\mathrm{v}$ \\
\hline & Teknik & & $\mathrm{v}$ & & \\
\hline & Aplikasi & $\mathrm{v}$ & $\mathrm{v}$ & $\mathrm{v}$ & $\mathrm{v}$ \\
\hline & Metode penyampaian & & & & \\
\hline Tata Kelola & Kebijakan & $\mathrm{v}$ & $\mathrm{v}$ & $\mathrm{v}$ & $\mathrm{v}$ \\
\hline \multirow[t]{5}{*}{ (governance) } & Struktur & & $\mathrm{v}$ & & \\
\hline & Penyesuaian (compliance) & & & & \\
\hline & Tata layanan & & & & \\
\hline & Keamanan & & & & \\
\hline & dan privasi & & & & \\
\hline
\end{tabular}

(Sumber: Interpretasi hasil penelitian, 2015)

Dari proses identifikasi yang dilakukan pada Tabel 3, dapat dikatakan bahwa penerapan Big Data di LKPP berada pada tahap pre-adoption. Hal ini dicirikan dari lembaga telah mulai mempersiapkan dan menginvestasikan infrastruktur dan mengujicoba beberapa aplikasi untuk Big Data analitik, telah mempunyai kebijakan, perencanaan proses bisnis dan cakupan yang akan dilakukan dengan Big Data. Namun, strategi dan budaya implementasi, serta mekanisme kerja belum terbangun dan dilaksanakan. Selain itu, arsitektur dari infrastruktur yang dibangun serta tata kelolanya belum dapat ditunjukkan. Demikian pula dengan penerapan Big Data di Ditjen Pajak, dapat dikategorikan berada pada tahap pre-adoption. Ciri yang terlihat adalah sudah ada kesadaran dari lembaga dan pimpinan untuk melakukan perbaikan proses bisnis dengan melibatkan teknologi Big Data. Lembaga juga sudah mulai bereksperimen dengan beberapa tools pendukung Big Data, namun sistem analitik belum berjalan dan dipakai untuk memecahkan masalah. Hal yang tidak jauh berbeda terjadi di Badan Informasi Geospasial (BIG), implementasi Big Data pada lembaga tersebut berada pada tahap preadoption. Lembaga telah mengantisipasi penggunaan Big Data dalam proses bisnisnya, dan telah menginvestasikan infrastruktur pendukung, namun mekanisme kerja dan budaya analitik belum terlaksana. Kekuatan BIG menuju Big Data terletak pada ketersediaan beragam data yang update, real time, terintegrasi dan terbuka, sehingga memungkinkan pemanfaatannya untuk kepentingan berbagai sektor. Sementara penerapan teknologi Big Data di Pemkot Bandung sudah jauh lebih matang, sehingga dapat dikategorikan berada pada tahap corporate adoption. Hal ini dicirikan dari infrastruktur penunjang Big Data yang telah 
terintegrasi, dimana end users (masyarakat, SKPD, kecamatan) telah dilibatkan dalam sistem dan mendapatkan manfaat. Dengan sistem Big Data analitik yang ada, dapat diketahui kondisi real dilapangan sehingga membantu pimpinan mengambil keputusan dan meningkatkan kualitas layanan serta fasilitas pemerintah kepada masyarakat. Untuk dapat mencapai kategori mature/visionary, beberapa hal yang perlu ditingkatkan dalam sistem Big Data analitik Pemkot Bandung yaitu menambah infrastruktur cloud, meningkatkan aspek keamanan data, serta meningkatkan budaya kerja dan awareness dari pegawai dan masyarakat setempat untuk memanfaatkan teknologi Big Data yang telah dibangun.

\section{Peluang Penerapan Big Data Lainnya}

Selain pemanfaatan di keempat lembaga diatas, bentuk-bentuk penerapan teknologi Big Data di lembaga pemerintahan masih sangat luas, baik yang sudah diimplementasikan maupun yang masih dalam perencanaan. Pemerintah Provinsi DKI Jakarta sudah menerapkan Jakarta Smart City, yaitu suatu aplikasi untuk memberikan informasi kepada masyarakat informasi terkait kondisi Jakarta. Sementara pemerintah Kota Banda Aceh menerapkan open data melalui sebuah portal yang telah menyediakan 86 dataset dari sektor pendidikan, kesehatan, transportasi, dan sektor lainnya, dalam format CSV. Data ini bersifat terbuka sehingga dapat dipakai untuk kebutuhan riset, pembuatan kebijakan, dan penulisan berita ${ }^{4}$.

Beberapa pakar dan praktisi mengutarakan peluang penerapan Big Data lainnya. Pakar Teknologi Informasi Rudi Rusdiah mengatakan Big Data analitik bisa dimanfaatkan untuk mengantisipasi berbagai dampak bencana alam di Tanah Air, misalnya untuk mengantisipasi dampak El Nino, dengan sintesis data dari citra satelit cuaca, GPS dan penginderaan jauh, sensor-sensor cuaca BMKG (Badan Meteorologi Klimatologi Geofisika) serta stok pangan BULOG dan Kementerian Pertanian hingga BPS, Kementerian Pertahanan, Kementerian Lingkungan Hidup dan Hutan, Kementerian Kelautan, hingga Kementerian Kominfo. Jika data yang dihasilkan oleh BPS sesuai dengan kondisi kekinian, lanjutnya, Indonesia tidak perlu tergantung pada data analisis global seperti IDC, Google, Bank Dunia bahkan data global CIA, hingga internet ${ }^{5}$.

Selain itu, ada pula rencana Pemerintah untuk menyusun Big Data yang merangkum data dari berbagai instansi terkait dengan pariwisata. Hal ini dimaksudkan agar data pariwisata di Indonesia bisa terintegrasi ${ }^{6}$. Pada Big Data analitik akan terdapat

${ }^{4}$ https://m.tempo.co/read/news/2016/04/21/078764748/bigdata-akan-mewarnai-kebijakan-publik-di-indonesia, tanggal 21 April 2016, diakses tanggal 29 Agustus 2016.

${ }^{5} \mathrm{http} / / / \mathrm{www}$.antaranews.com/berita/511290/analisis-data-bisadimanfaatkan-untuk-antisipasi-dampak-

bencana?utm_source=fly\&utm_medium $=$ related $\& u t m \_c a m p a i$ gn=news, tanggal 8 Agustus 2015, diakses tanggal 29 Agustus 2016.

${ }^{6} \mathrm{http}: / /$ mediaindonesia.com/news/read/34950/pemerintahsusun-big-data-pariwisata/2016-03-18, tanggal 18 Maret 2016, diakses tanggal 29 Agustus 2016. 
data jumlah wisatawan, agenda acara daerah, lokasi, dan keterangannya, melalui pengolahan seluruh data dari berbagai sumber seperti BPS, imigrasi, hingga pos lintas batas. Diharapkan langkah tersebut dapat membantu menentukan strategi promosi wisata dengan lebih tepat dan maksimal di tiap daerah, sehingga mampu mendongkrak target kunjungan wisatawan pada tahun 2019.

Pemanfaatan teknologi Big Data di pemerintah kota dapat dikembangkan dari sekedar memantau kepadatan lalu lintas di beberapa titik melalui CCTV untuk perencanaan transportasi umum, dengan mengetahui berapa banyak orang yang berpindah (comute) dari satu daerah ke daerah lain, sehingga pemerintah dapat menyediakan solusi transportasi yang lebih baik. Lembaga BPJS juga dapat bekerjasama dengan Ditjen Pajak untuk menghindari fraud atau penipuan/kecurangan yang dilakukan sebuah perusahaan dalam membayar BPJS di bawah nominal seharusnya.

Menurut Peter Sugiapranata, Sales Director SAS Indonesia, saat ini sudah ada 14 institusi pemerintahan Indonesia yang bekerja sama dengan perusahaan SAS dalam penggunaan Big Data analytic $^{7}$. Lembaga riset Gartner memperkirakan penggunaan big data analytics akan meningkat $70 \%$ pada tahun 2020 , seiring dengan tumbuhnya

${ }^{7}$ http://www.sas.com/en_id/news/pressreleases/2015/october/sas-indonesia-dorong-solusi-big-datauntuk-layanan-publik.html, tanggal 20 Oktober 2015, diakses tanggal 29 Agustus 2016. kesadaran akan pentingnya pemanfaatan analytics di berbagai bisnis dan institusi ${ }^{8}$.

Tetapi dibalik penggunaan Big Data tersebut, yang terpenting adalah perencanaan yang matang dalam memutuskan pemanfaatanya agar sesuai dengan kebutuhan organisasi. Jangan sampai pemerintah seperti latah dengan beramai-ramai menggunakan Big Data dan mengalokasikan anggaran yang fantastis untuk implementasinya, tanpa tujuan dan perencanaan yang jelas. Sebab data besar menimbulkan peluang besar dan tantangan besar pada saat yang sama, namun kekuatannya tidak bergantung pada teknik pengolahan data yang digunakan, tetapi lebih pada bagaimana hasilnya dapat menjadi pengetahuan yang dapat digunakan untuk membuat keputusan cerdas (Charles, Vincent, \& Tatiana, 2013).

\section{Tantangan Penerapan Big Data di Pemerintahan}

Banyak pihak sepakat bahwa penerapan teknologi Big Data membawa keuntungankeuntungan bagi tujuan dan performa organisasi. Namun, implementasinya bukan tanpa kendala. Dari hasil wawancara dengan pengelola teknologi informasi di empat lembaga yang diteliti, dapat disimpulkan beberapa tantangan dalam adopsi teknologi Big Data di pemerintahan Indonesia, yaitu:

1. Ketersediaan Data

Salah satu kunci untuk melakukan analisis Big Data tentu ketersediaan data. Akses terhadap data,

${ }^{8}$ http://inet.detik.com/read/2015/03/06/071809/2851164/319/s etelah-big-data-tren-apa-yang-bakal-booming, tanggal 6 Maret 2015, diakses tanggal 29 Agustus 2016. 
baik data lama maupun data baru dapat menjadi hambatan untuk Big Data, terlebih pada data lama yang tersimpan dalam bentuk yang berbeda-beda dan beragam bahkan seringkali dalam bentuk fisik. Akses terhadap data baru juga membutuhkan usaha yang lebih karena diperlukannya izin dan lisensi untuk mengakses data-data non-publik secara legal. Terlebih jika terjadi ego sektoral antar instansi sebagai pemilik data. Hal ini yang dirasakan oleh para penyedia jasa dan informasi yang menerapkan Big Data analitik di Indonesia, bahwa fase pengumpulan data menjadi tantangan utama. Sebetulnya di Indonesia, data untuk berbagai jenis kebutuhan sudah tersedia dan banyak, namun sumbernya tersebar, sehingga dibutuhkan usaha lebih untuk mendapatkan data terpadu secara nasional. Maka prinsip Sharing Data bahkan Open Data diperlukan.

Dengan semakin meluasnya penggunaan Big Data, semangat open data semakin kencang disuarakan khususnya terkait public sector information (PSI). Maksud dari open data disini mencakup dua fitur dasar, yaitu bahwa data harus tersedia untuk umum bagi siapa saja yang ingin menggunakannya, dan secara legal memungkinkan untuk digunakan kembali. Data yang terbuka juga harus relatif mudah digunakan, meskipun ada klasifikasi "keterbukaan" tersebut, dan tersedia secara gratis atau dengan biaya minimal. Gerakan open data di Indonesia telah terwujud dalam berbagai inisiatif, salah satunya pembentukan data.go.id. Dikatakan dalam situsnya bahwa data.go.id adalah portal resmi data terbuka Indonesia yang terdiri atas dan tidak terbatas hanya
Kementerian, lembaga pemerintahan, pemerintahan daerah, dan semua instansi lain yang terkait yang menghasilkan data yang berhubungan dengan Indonesia. Disana juga disediakan data dalam format yang mudah dicari, diakses serta digunakan dengan harapan pengguna situs dapat memanfaatkan data yang tersedia seluas-luasnya dan seinovatif mungkin demi terwujudnya Indonesia yang lebih baik. Seluruh kumpulan data yang ada di dalam portal ini dikategorikan sebagai domain publik sehingga tidak diperkenankan mengandung informasi yang mengandung rahasia negara, rahasia pribadi atau hal-hal lainnya yang diatur dalam Undang-Undang Nomor 14 Tahun 2008 tentang Keterbukaan Informasi Publik ${ }^{9}$.

Walaupun istilah open data berkembang menjadi bahasan tersendiri, keterkaitan antara konsep Big Data, open data dan open government dapat ditunjukkan dalam Diagram Venn berikut.

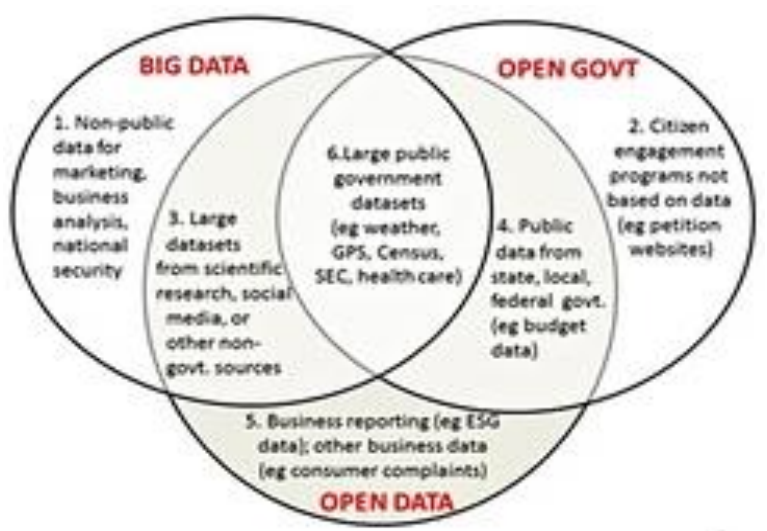

Gambar 9. Keterkaitan Big Data, open data dan open government

(Sumber : komangaryasa.com/wpcontent/uploads/2014/12/gambar-3.jpg)

\footnotetext{
${ }^{9}$ http://data.go.id/, diakses tanggal 29 Agustus 2016
} 


\section{Standarisasi Data Pemerintah}

Sejalan dengan prinsip open data, data yang tersedia di Kementerian, lembaga pemerintahan, dan pemerintahan daerah, perlu disajikan dalam bentuk standar/platform tertentu yaitu format yang dapat dengan mudah digunakan kembali, dapat dibaca dengan mesin dan bersifat interoperabilitas, misalnya dalam format .xls atau .csv dan bukan dalam bentuk scan dokumen atau scan pdf. Dengan demikian, dapat meningkatkan pemanfaatan data pemerintah, meningkatkan transparansi dan akuntabilitas pemerintah, serta meningkatkan partisipasi masyarakat dalam mengawal pembangunan.

Selain itu, adanya standarisasi data pemerintah dapat dilanjutkan dengan integrasi data antar instansi untuk efisiensi dan mencegah redundansi. Misalnya, ketika seseorang ingin mengurus Surat Ijin Mengemudi (SIM), data kependudukan yang harus diisikan pada form SIM dapat ditarik dari data Kartu Tanda Penduduk (KTP) yang sudah tersedia di Bagian Kependudukan Kementerian Dalam Negeri. Atau ketika tenaga kerja mengajukan perijinan kerja pada Dinas Ketenagakerjaan dapat dilakukan proses pengecekan data dari data kependudukan.

\section{Privasi Data}

Di satu sisi dibutuhkan keterbukaan data, namun disisi lain privasi merupakan isu yang sensitif dan sering tercidera melalui kemajuan teknologi. Privasi berhubungan dengan data-data pribadi seseorang yang harus dilindungi. Data-data yang digunakan sebagai Big Data oleh misalnya industri telekomunikasi maupun perbankan, yang diperoleh langsung dari konsumen, banyak yang merupakan data pribadi dan sangat rawan untuk disalahgunakan oleh pihak lain. Penggunaan data pribadi seseorang harus atas persetujuan yang bersangkutan jika akan digunakan pihak lain. Oleh karena itu, pemerintah saat ini sedang menyusun RUU tentang Perlindungan Data dan Informasi Pribadi untuk melindungi data-data pribadi warga negara. Penggunaan teknologi Big Data yang tidak bijak rawan akan isu privasi data. Keamanan warga negara harus diperhatikan, dimana tindakan kriminal yang mungkin muncul akibat terbukanya informasi harus diantisipasi, terlebih yang berpengaruh terhadap kestabilan negara.

Sejauh ini, penerapan Big Data di Indonesia wajib tunduk pada peraturan perundang-undangan yang telah mengatur perlindungan data atau informasi dan pembatasan penggunaannya, di antaranya UU Informasi dan Transaksi Elektronik, UU Keterbukaan Informasi Publik, UU Perbankan, dan UU Perlindungan Konsumen.

\section{Kompetensi SDM}

Dalam memanfaatkan Big Data di pemerintahan idealnya dibutuhkan SDM yang ahli dibidang analisis data (data scientist), memiliki kemampuan analitik, keahlian pemrograman komputer, dan kreativitas untuk menentukan metode baru yang dapat dilakukan untuk mengumpulkan, menginterpretasi dan menganalisis data. Walaupun mungkin data scientist tidak mengembangkan analytic tools sendiri, namun harus mampu memilah aneka tools yang akan dipakai, serta menyeleksi dan mengorganisasi data yang akan dianalisis. 


\section{Infrastruktur Penunjang}

Semua perangkat analisis Big Data yang beredar di pasar dapat dipakai oleh pemerintah. Pemerintah dapat menggunakan tools Big Data dari pihak ketiga yang telah disesuaikan dengan kebutuhan, maupun membangun dan memelihara sendiri sistem Big Data yang dibutuhkan. Perhitungan cost benefit analysis terhadap kedua pilihan tersebut perlu dilakukan sesuai dengan tujuan penggunaannya. Untuk beberapa kasus tertentu dibutuhkan analisis Big Data dengan Natural Language Processing (NLP) yang dapat mengolah percakapan digital Bahasa Indonesia, hal ini yang menjadi keterbatasan beberapa sistem yang tersedia open source.

Jika temuan diatas dibandingkan dengan hasil penelitian yang dilakukan oleh Capgemini Consulting (2014) dan TDWI (2013) yang mengidentifikasi berbagai tantangan implementasi
Big Data di beberapa organisasi global di beberapa negara (Tabel 4), maka ditemukan kesamaan bahwa isu terkait data menjadi tantangan utama, baik dalam hal menyediakan dan mengintegrasikan data yang diperlukan untuk menghasilkan analisis bisnis yang tepat, maupun isu keamanan data dan privasi data. Selain itu, diketahui pula bahwa tantangan implementasi Big Data di lembaga pemerintahan, tidak jauh berbeda dengan implementasinya di organisasi lain seperti perusahaan, dimana faktor ketrampilan SDM dan infrastruktur penunjang menjadi tantangan yang harus diperhatikan. Hal ini terkait kehadiran teknologi Big Data yang masih tergolong baru untuk diimplementasikan dalam organisasi. Maka tidak heran jika diprediksi bahwa data scientist menjadi pekerjaan yang paling menjanjikan di abad 21(Davenport, Thomas, \& D.J, 2012)

Tabel 4. Berbagai tantangan implementasi Big Data di organisasi

\begin{tabular}{|c|c|c|c|}
\hline \multicolumn{2}{|l|}{ Big Data Survey-Capgemini Consulting (2014) } & \multicolumn{2}{|l|}{ Predictive Analytics Study-TDWI (2013) } \\
\hline Tantangan & f & Tantangan & $f$ \\
\hline Kompleksitas integrasi data & $35 \%$ & Data yang tersebar di berbagai tempat & $46 \%$ \\
\hline Memulai dengan proyek yang tepat & $30 \%$ & $\begin{array}{l}\text { Tidak adanya business case yang jelas terkait } \\
\text { pembiayaan dan implementasi }\end{array}$ & $39 \%$ \\
\hline Merancang sistem big data & $29 \%$ & $\begin{array}{l}\text { Tidak efektifnya koordinasi tim implementasi } \\
\text { Big Data analitik dalam organisasi }\end{array}$ & $35 \%$ \\
\hline Kurangnya ketrampilan SDM & $28 \%$ & $\begin{array}{l}\text { Ketergantungan pada legalitas untuk } \\
\text { pemrosesan dan manajemen data }\end{array}$ & $31 \%$ \\
\hline Kepemilikan data dan isu politis lainnya & $21 \%$ & $\begin{array}{l}\text { Model pengaturan Big Data analitik yang tidak } \\
\text { efektif }\end{array}$ & $27 \%$ \\
\hline Kurangnya pembiayaan & $20 \%$ & Kurangnya dukungan dari pimpinan & $27 \%$ \\
\hline Keamanan data, privasi, dan tata kelola & $20 \%$ & $\begin{array}{l}\text { Kurangnya ketrampilan SDM bidang Big Data } \\
\text { analitik }\end{array}$ & $25 \%$ \\
\hline Berurusan dengan real-time data & $16 \%$ & $\begin{array}{l}\text { Kurangnya kejelasan perangkat dan teknologi } \\
\text { untuk Big Data }\end{array}$ & $22 \%$ \\
\hline $\begin{array}{l}\text { Tidak dapat membangun business case yang } \\
\text { menarik }\end{array}$ & $16 \%$ & $\begin{array}{l}\text { Biaya pengadaan perangkat dan infrastruktur } \\
\text { tertentu untuk Big Data }\end{array}$ & $18 \%$ \\
\hline Kualitas data yang buruk & $14 \%$ & Keamanan data dan privasi & $15 \%$ \\
\hline
\end{tabular}


Arsitektur data warehouse yang ada

Tipe dan sumber data yang tidak matang

Infrastruktur yang tidak memadai

Kurangnya metadata dan skema untuk big

data

Biayanya terlalu tinggi

Isu budaya lainnya

Sumber: (Colas, 2014)
$12 \%$ Keengganan untuk berubah dari dalam $12 \%$ organisasi

$11 \%$

$9 \%$

$9 \%$

$6 \%$

$4 \%$

\section{PENUTUP}

Peranan data sangat penting terutama memasuki era ledakan data atau "Big Data". Ketersediaan data skala besar dan murah dewasa ini seharusnya mendorong berbagai pihak untuk memanfaatkannnya melalui implementasi Big Data analitik. Peluang dan manfaat penerapan Big Data sangat potensial termasuk di pemerintahan. Dengan menggunakan data, kebijakan publik bisa didesain dan diimplentasikan lebih efektif dan tepat untuk mencapai sasaran.

Dari hasil penelitian yang telah dilakukan secara kualitatif, dapat disimpulkan bahwa dari empat lembaga yang diteliti, tiga diantaranya yaitu Lembaga Kebijakan Pengadaan Barang/Jasa Pemerintah (LKPP), Direktorat Jenderal Pajak Kementerian Keuangan, dan Badan Informasi Geospasial (BIG) berada pada tahap pre-adoption, mengacu pada TDWI Big Data Maturity Model. Sementara Pemerintah Kota Bandung dapat dikategorikan berada pada tahap corporate adoption. Terkait tantangan dalam adopsi teknologi Big Data di pemerintahan Indonesia dapat disimpulkan 5 hal, mencakup ketersediaan data, standarisasi data pemerintah, privasi data, kompetensi SDM, serta infrastruktur penunjang.

Untuk itu, instansi-instansi pemerintah perlu secara cermat merencanakan dan mengimplementasikan teknologi Big Data, dimulai dari koordinasi antar lembaga pemerintah serta berbagi data dan integrasi data untuk lebih meningkatkan pelayanan publik.

Untuk penelitian selanjutnya, dapat dilakukan survei/pengukuran kuantitatif terhadap tingkat kematangan implementasi teknologi Big Data menggunakan instrumen penilaian yang telah dikembangkan oleh TDWI, pada lebih banyak instansi pemerintah. Dengan demikian, didapatkan gambaran yang lebih komprehensif tentang implementasi teknologi Big Data di lembaga pemerintahan Indonesia.

\section{UCAPAN TERIMA KASIH}

Peneliti mengucapkan terima kasih kepada pihakpihak yang telah membantu dalam menyelesaikan penelitian ini.

\section{DAFTAR PUSTAKA}

Alamsyah, A. (2015). (Big) Data Analytics for Economics, Business and Management: A Social Network Approach. In Workshop Big Data Puslitbang Aptika dan IKP,tanggal 19 Mei 2015. Puslitbang Aptika dan IKP. 
Aryasa, K. (2015). Big Data: Challenges and Opportunities. In Workshop Big Data Puslitbang Aptika dan IKP, tanggal $19 \mathrm{Mei}$ 2015. Puslitbang Aptika dan IKP.

Chandarana, Parth, \& Vijayalakshmi, M. (2014). Big Data analytics frameworks: Circuits, Systems, Communication and Information Technology Applications (CSCITA). In International Conference on IEEE 2014. IEEE.

Charles, Vincent, \& Tatiana, G. (2013). Achieving Competitive Advantage through Big Data: Strategic Implications. Middle-East Journal of Scientific Research, 16(8), ISSN 19909233.

Colas, M. (2014). Cracking the Data Conundrum: How Successful Companies Make Big Data Operational. Capgemini Consulting.

Davenport, Thomas, H., \& D.J, P. (2012). Data Scientist: The Sexiest Job of the 21st Century. Harvard Business Review.

Djuniardi, I. (2015). Perjalanan Menuju Implementasi Big Data: Pengalaman Direktorat Jenderal Pajak. In Konferensi Big Data Indonesia 2015, tanggal 1 Desember 2015. Direktorat Jenderal Pajak.

Friedman, J. (1997). Data Mining and Statistics: What are the Connections?

Halper, Fern, \& Krishnan, K. (2013). TDWI Big Data Maturity Model Guide: Interpreting Your Assessment Score. Retrieved from tdwi.org

Khafid. (2015). Pengelolaan Data dan Informasi Geospasial. In Konferensi Big Data Indonesia, tanggal 1 Desember 2015.

Rainer, Kelly, R., \& Cegielski., C. G. (2009). Introduction to Information Systems. John Wiley \& Sons (Asia) Pte Ltd. http://www.antaranews.com/berita/477310/tigabidang-usaha-pengguna-utama-big-data-diindonesia, tanggal 30 Januari 2015, diakses tanggal 29 Agustus 2016.

https://m.tempo.co/read/news/2016/04/21/0787647 48/big-data-akan-mewarnai-kebijakanpublik-di-indonesia, tanggal 21 April 2016, diakses tanggal 29 Agustus 2016.

http://www.ibmbigdatahub.com/infographic/fourvs-big-data, diakses tanggal 15 November 2015.

http://nasional.kontan.co.id/news/ditjen-pajakmenggali-data-lewat-media-sosial, tanggal 12 Oktober 2015, diakses tanggal 15 November 2015.

http://www.antaranews.com/berita/511290/analisis -data-bisa-dimanfaatkan-untuk-antisipasidampak-

bencana?utm_source=fly\&utm_medium $=$ rel ated\&utm_campaign=news, tanggal 8 Agustus 2015, diakses tanggal 29 Agustus 2016.

http://mediaindonesia.com/news/read/34950/pemer intah-susun-big-data-pariwisata/2016-03-18, tanggal 18 Maret 2016, diakses tanggal 29 Agustus 2016.

http://www.sas.com/en_id/news/pressreleases/2015/october/sas-indonesia-dorongsolusi-big-data-untuk-layanan-publik.html, tanggal 20 Oktober 2015, diakses tanggal 29 Agustus 2016.

http://inet.detik.com/read/2015/03/06/071809/2851 164/319/setelah-big-data-tren-apa-yangbakal-booming, tanggal 6 Maret 2015, diakses tanggal 29 Agustus 2016.

http://data.go.id/, diakses tanggal 29 Agustus 2016. 